\title{
Representasi Nilai Kosmologi Pada Wujud Lokal Bangunan Hunian Bali Aga
}

\author{
Ida Ayu Dyah Maharani, Imam Santosa, Prabu Wardono \\ PFSRD, Institut Teknologi Bandung (ITB) \\ Jalan Ganesha 10 Bandung
}

\begin{abstract}
Bali Aga architecture is the second oldest architecture in Bali lasted the 8th to 13th century which there were two important events that brought acculturation impact: the arrival of Resi Markandeya came from India who brought Budha Mahayana belief and Empu Kuturan came from East Java who brought Hindu belief. Before those, Bali Aga community had a cosmological ideology as their belief and still visible in every thought, behavior and artifacts including their housing.

This qualitative research is performed uses ethnography method to be able to trace the representation of cosmological ideology, especially in the form of local housing. The result of this study describes some cosmological ideologies of community in each Bali Aga villages cannot regarded as the same because it influenced by each local wisdom. However, the diversity has the same value, idea and purpose to put the universe as the main orientation. Bali Aga community's submission to the universe makes their housing are able to survive with their identity until now.
\end{abstract}

Keywords: Bali Aga, cosmology, housing, ethnography

\begin{abstract}
ABSTRAK
Arsitektur Bali Aga merupakan arsitektur tertua kedua di Bali yang masa kemunculannya meliputi kurun waktu abad ke-8 s.d 13, dimana terdapat dua peristiwa akulturasi penting yaitu kedatangan Resi Markandeya dari India yang membawa ajaran Budha Mahayana dan Empu Kuturan dari Jawa Timur yang membawa ajaran Hindu. Sebelum masuknya kedua budaya tersebut, masyarakat Bali Aga memiliki pandangan kosmologi sebagai anutan kepercayaan yang masih terlihat hingga kini dalam setiap pemikiran, perilaku dan artefak bangunan huniannya.

Penelitian kualitatif ini dilakukan dengan menggunakan metode etnografi untuk dapat menelusuri representasi pandangan kosmologi masyarakat, khususnya dalam wujud lokal bangunan huniannya. Hasil penelitian ini menjelaskan beberapa pandangan kosmologi di desa-desa Bali Aga ternyata tidak dapat dianggap sama karena sangat dipengaruhi masingmasing local wisdom. Namun keberagaman tersebut tetap mengandung nilai, maksud dan tujuan yang sama dengan menjadikan alam semesta sebagai orientasi yang utama. Keberserahan diri masyarakat Bali Aga kepada alam semesta ini menjadikan bangunan huniannya mampu bertahan dengan identitasnya hingga kini.
\end{abstract}

Kata kunci: Bali Aga, kosmologi, bangunan hunian, etnografi 


\section{PENDAHULUAN}

Pada awal cara manusia bertempat tinggal, mereka hidup dengan cara nomaden. Mereka bertempat tinggal di gua atau ceruk yang telah disediakan oleh alam, dan ketika lingkungan di sekitarnya tidak lagi bersahabat maka mereka pun berpindah tempat. Cara bertempat tinggal yang paling primitif ini mengacu pada belum adanya keinginan dan kemampuan membangun, serta tradisi pertukangan pada saat itu juga belum berkembang (Gartiwa, 2011). Namun seiring dengan pemahaman yang semakin mendalam tentang alam, manusia kemudian mencoba beradaptasi dan benar-benar mendiami suatu daerah tertentu dengan cara membuat sendiri huniannya. Amos Rapoport dalam Gartiwa (2011) mengatakan bahwa pada awalnya hunian dibuat sebagai upaya pemenuhan kebutuhan akan shelter serta mulai berupaya mengenali dan bersahabat dengan alam termasuk cara kerjanya.

Alam yang dimaksud di sini adalah yang bersifat fisik dan non fisik. Secara keseluruhan, kelompok manusia pada jaman dulu memiliki suatu pemahaman bahwa segala kejadian fisik (seperti perubahan cuaca dan arah angin, terjadinya badai, gunung meletus, gempa bumi dan sebagainya) selalu berkaitan dengan dewa-dewa. Secara naluriah manusia mempelajari alam sekitarnya dengan cara mengaitkan hal-hal fisik dan non fisik (spiritualitas). Wahid (2013) menyebutkan bahwa alam sebagai lingkungan tinggalnya kemudian selalu menjadi bahan pertimbangan dalam proses perwujudan ungkapan-ungkapan hunian. Hal ini kemudian menjadi salah satu penyebab munculnya representasi nilai-nilai kosmologi yang dipercayainya pada wujud lokal bangunan hunian, salah satunya adalah bangunan hunian yang berada di desa-desa Bali Aga.

Bali Aga atau yang dikenal juga dengan Bali Kuno muncul dan berkembang dari abad masehi ke-8 (setelah berakhirnya jaman Bali Mula atau Bali Purba yang masyarakatnya masih hidup nomaden) hingga sekitar abad ke-13, sebelum datangnya ekspedisi mahapatih Gajah Mada dari Majapahit ke Bali atau sebelum dimulainya jaman Bali Madya atau Bali Arya (Ardika, 2013). Kata Aga diyakini memiliki arti gunung (walaupun belum ditemukan catatan tertulis sebagai pembuktiannya), maka desadesa Bali Aga biasanya dapat ditemui di daerah-daerah pegunungan di Bali seperti di kabupaten Buleleng (di bagian utara pulau Bali), Bangli, dan Karangasem (di bagian timur pulau Bali).

Masyarakat Bali Aga meyakini bahwa alam semesta diatur dan dibagi menurut sistem tertentu dengan hirarkinya masing-masing sehingga menciptakan suatu pengelompokan terhadap segala sesuatu

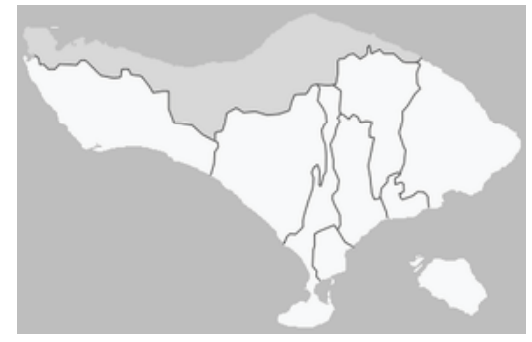

(a)

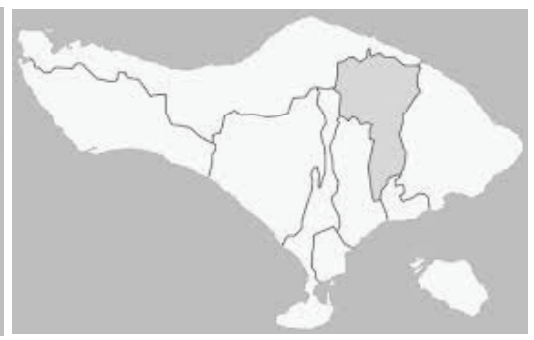

(b)

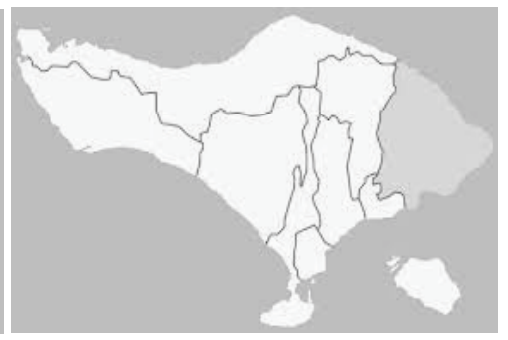

(c)

Gambar 1

Lokasi pengembangan desa-desa Bali Aga (pada bagian terblok)

di kabupaten Buleleng (a), kabupaten Bangli (b) dan Kabupaten Karangasem (c) Sumber: http://id.wikipedia.org/wiki/Kabupaten_Buleleng (a), http://id.wikipedia.org/ wiki/Kabupaten_Bangli (b), http://id.wikipedia.org/wiki/Kabupaten_Karangasem (c) 
yang ada dalam kosmos dan seluruh hidup harus disesuaikan menurut sistem kosmos (Runa, 2007). Menurut Runa (2007), masyarakat Bali Aga mempercayai adanya dua dunia yaitu dunia pertama pada saat mereka masih hidup dan dunia kedua saat sudah meninggal yang disebut juga sebagai dunia roh leluhur, serta mempercayai bahwa kehidupan di kedua dunia tersebut akan saling berlanjut. Leluhur atau anggota keluarga yang sudah meninggal pun kemudian dibedakan lagi berdasarkan kelengkapan upacara penyucian yang telah dilaluinya. Pertama, kelompok yang sudah meninggal namun belum melalui upacara penyucian yang lengkap, maka mereka disebut dengan istilah pitara dan dipuja di merajan (area suci sebagai tempat persembahyangan) tempat tinggal mereka masing-masing. Kelompok kedua adalah yang sudah meninggal dan sudah melalui upacara penyucian secara lengkap, maka mereka disebut dengan istilah dewa, dewara, batara atau sanghyang. Leluhur yang sudah disucikan dengan upacara lengkap ini tidak lagi dianggap sebagai individu-individu yang terpisah, mereka dianggap telah bergabung dengan nenek moyangnya di surga yang berada di atas dunia nyata yang dilambangkan dengan tempat tertinggi dalam dunia nyata yaitu berupa pegunungan. Berdasarkan uraian tersebut maka gunung dianggap sebagai arah orientasi hulu dan selalu dihubungkan dengan sesuatu yang ilahi, surgawi, suci dan sakral.

Masih menurut Runa (2007), dengan demikian masyarakat Bali Aga memandang huniannya sebagai sesuatu yang bukan homogen karena selalu terdapat pembagian yang saling mengisi. Pembagian ini seperti yang diungkapkan dalam istilah hulu yang merujuk ke arah gunung dan teben (bawah) yang merujuk ke arah laut. Masyarakat memandang gunung sebagai tempat kediaman arwah nenek moyang atau leluhur yang sudah didewakan sehingga gunung dianggap sebagai sumber yang utama. Sebaliknya, pengertian teben dihubungan dengan segala sesuatu yang duniawi, nista dan kematian. Segala sesuatu yang memiliki nilai saling bertentangan kemudian direpresentasikan dengan perlawanan hulu dan teben. Berdasarkan kepercayaan ini maka masyarakat Bali Aga juga dianggap memiliki filosofi dasar Rwa Bhineda yang berarti adanya dua elemen yang memiliki nilai saling bertentangan namun akan selalu tetap ada bersama-sama keberadaannya bagai dua sisi keping uang yang tidak terpisahkan (Reuter, 2005). Adanya barisan pegunungan yang membujur di tengah pulau Bali dari barat ke timur, menjadikan Bali terbagi menjadi dua bagian yaitu utara dan selatan, yang menyebabkan arah hulu dan teben yang dipercayai oleh masyarakat yang bertempat tinggal di Bali Utara dan Bali Selatan tersebut saling terbalik. Sebagai konsekuensinya menurut Runa (2007) adalah ketika membangun permukiman maka masyarakat Bali Aga yang berada di kedua daerah tersebut selalu menyesuaikannya dengan pandangan kosmologi yang dipercayai di masing-masing daerahnya.

Keberadaan sumbu atau axis pada sebuah permukiman yang menghubungkan kedua nilai yang saling bertentangan tersebut berupa jalan utama yang membujur dari arah $h u l u$ (gunung sebagai arah orientasi yang utama karena dianggap sebagai area yang paling sakral) ke teben atau sebaliknya. Ruang permukiman secara simbolis selalu dibagi menjadi tiga bagian. Pertama, bagian $h u l u$ permukiman yang disimbolkan sebagai dunianya roh leluhur dan Tuhan yang dimanifestasikan sebagai penguasa dan pelindung desa, dan pada area ini biasanya terdapat pura (tempat persembahyangan bagi masyarakat desa). Bagian kedua yaitu di bagian tengah-tengah permukiman yang berupa kumpulan pekarangan hunian termasuk ruang bersama, yang merupakan dunianya manusia atau dunia profan. Tera- 


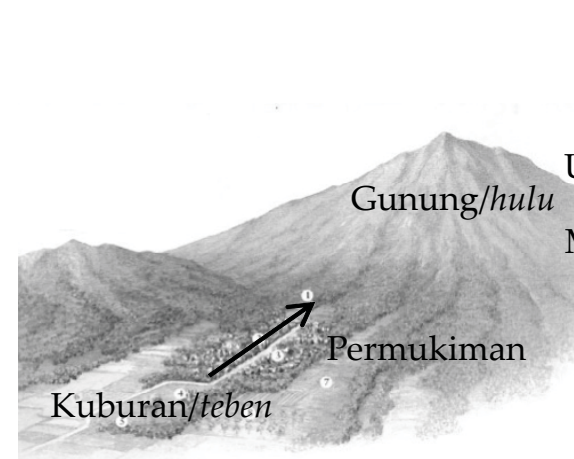

(a)

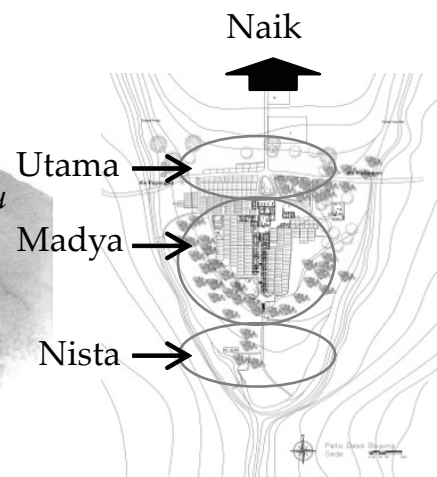

(b)

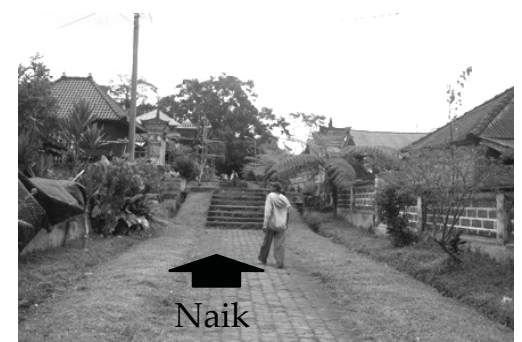

(c)

Gambar 2

Tata letak permukiman Bali Aga yang memiliki orientasi utama ke arah gunung (a), direpresentasikan pada tata ruang permukiman seperti pada desa Bayung Gede

(b) dan Pengotan (c) yang juga tetap memanfaatkan kondisi topografi bertransis

untuk menunjukkan pembagian ruang berdasarkan nilai utama-madya-nista

Sumber gambar: Davison, 2003 (a), Manik, 2007 (b), dokumentasi penulis, 2015 (c)

khir, bagian teben dianggap sebagai area kotor yang terletak berlawanan dengan hulu dan biasanya pada area ini terdapat setra (kuburan). Hasil observasi penulis di lapangan dapat terlihat bahwa secara topografi, lahan permukiman Bali Aga umumnya bertransis. Perbedaan ketinggian lahan permukiman yang menyerupai lereng ini masih tetap dibiarkan untuk menunjukkan hirarki nilai kosmologi masing-masing areanya. Level lahan yang tertinggi merupakan area hulu (utama dan suci), level lahan yang lebih rendah merupakan area madya sebagai tempat tinggal penduduk dan lahan dengan level terendah merupakan area teben (nista).

Representasi nilai-nilai kosmologi pada permukiman Bali Aga seperti dalam penjelasan sebelumnya tersebut dapat dilihat adanya indikator-indikator kosmologi yang selalu ada sebagai berikut:

- Keberadaan sumbu utama penghubung hulu (menuju gunung) dan teben (menuju laut).

- Pembagian area berdasarkan perbedaan nilai kesakralan menjadi utama-madya-nista.

- Pemanfaatan perbedaan ketinggian lahan untuk menunjukkan hirarki nilai kosmologi ketiga area tersebut, dengan menempatkan area utama pada lahan permukiman yang paling tinggi dan area nista pada lahan permukiman yang paling rendah.

Hal ini kemudian memunculkan pertanyaan apakah indikator-indikator kosmologi yang terlihat pada wujud permukiman Bali Aga tersebut juga dapat dilihat pada wujud pekarangan dan bangunan hunian masyarakatnya atau justru terdapat adanya varian yang selama ini belum dikenali? Untuk itulah perlu dilakukan penelitian lebih lanjut agar dapat membuktikan dan menjawab pertanyaan tersebut.

\section{METODE}

Penelitian ini merupakan penelitian kualitatif yang menggunakan metode etnografi yang memusatkan pada usaha penelitian untuk menemukan bagaimana masyarakat mengorganisasikan nilai-nilai kosmologi yang dimiliki dan merepresentasikannya dalam wujud pekarangan dan bangunan huniannya. Indikator-indikator kosmologi yang terlihat pada wujud permukiman Bali Aga dicoba untuk dilihat kembali keberadaannya dengan cakupan 
yang lebih kecil pada lingkungan tempat tinggal dengan fokusnya pada penataan pekarangan hunian, penataan ruang dalam hunian dan pada bentuk fisik bangunan hunian Bali Aga. Penelitian pada bangunan hunian di desa-desa Bali Aga ini bersifat empiris dengan melihat cara berarsitekturnya. Untuk menganalisis data, dalam penelitian kualitatif ini menggunakan metode deduktif yang diawali dengan kesimpulan adanya indikator-indikator kosmologi yang terdapat pada permukiman-permukiman Bali Aga yang dicoba untuk dilihat kembali keberadaannya dan dijelaskan permasalahan-permasalahan khusus pada pekarangan dan bangunan huniannya. Proses analisis data dimulai dengan menjabarkan data terkait pekarangan dan bangunan hunian Bali Aga yang telah diamati sebelumnya, kemudian melakukan reduksi data dengan cara membuat rangkuman inti.

\section{HASIL DAN PEMBAHASAN}

Pada uraian berikutnya ini merupakan pembahasan tentang representasi nilai-nilai kosmologi yang ditunjukkan melalui indikator-indikatornya dalam wujud pekarangan dan bangunan hunian Bali Aga yang dibatasi pada tiga fokus yaitu perwujudannya pada penataan pekarangan hunian, penataan ruang dalam hunian dan bentuk fisik bangunan hunian Bali Aga.

\section{A. Penataan Pekarangan Hunian}

Pada pekarangan hunian juga dapat dilihat pembagian area utama-madya-nista. Berbeda halnya dengan ketinggian lahan permukiman yang dimanfaatkan untuk menunjukkan hirarki nilai kosmologi, perbedaan area pada pekarangan hunian dengan masing-masing nilainya dibedakan dengan adanya perbedaan nilai aktivitas dan fasilitasnya yang membentuk zona-zona tertentu. Bentuk pengaturan unit bangunan dalam pekarangan di desa-desa Bali Aga sangat sederhana yaitu didasari oleh tata nilai hulu (ke arah gunung)-teben (ke arah laut). Konsep perletakan unit bangunan di dalam pekarangan sangat tergantung pada fungsi dan nilai kesakralan masing-masing bangunan. Area utama merupakan area suci untuk melakukan aktifitas persembahyangan dengan fasilitas seperti merajan dengan beberapa pelinggih-nya. Area madya merupakan area untuk penghuninya melakukan aktifitasnya sehari-hari dengan fasilitas bangunan tinggal. Area nista merupakan area servis dengan fasilitas berupa dapur, kamar mandi dan kandang ternak. Orientasi masing-masing bangunan selalu menghadap ke halaman tengah atau natah. Hal ini menyiratkan suatu makna bahwa pada natah tersebut tercipta paduan unsur-unsur purusa (laki-laki) yang berwujud akasa atau ruang kosong, dengan unsur-unsur pradana (perempuan) yang berwujud pratiwi atau bumi. Pola sirkulasi pencapaian ke setiap bangunan di dalam pekarangan biasanya diawali dari area nista (tempat pintu masuk ke pekarangan berada) menuju natah (area madya), lalu menuju area utama. Konsep yang mempercayai hulu sebagai arah orientasi gunung dan teben sebagai orientasi laut, ternyata tidak selalu ditemukan pada seluruh desa Bali Aga. Hasil observasi penulis di lapangan, didapati adanya tiga jenis penataan bangunan dalam satu pekarangan.

\# Tipe Pertama: pada penataan pekarangan hunian tipe ini dapat dilihat sumbu utama selalu terbentang dari hulu ke teben seperti halnya sumbu utama pada penataan permukiman. Area utama selalu berada di zona hulu yang menuju ke arah gunung. Pintu masuk ke pekarangan selalu terletak pada area nista atau di zona teben yang menuju ke arah laut, yang dicapai melalui jalan kecil atau gang atau rurung.

Tipe penataan seperti ini yang paling sering didapati pada desa-desa Bali Aga lainnya di kabupaten Bangli seperti desa 


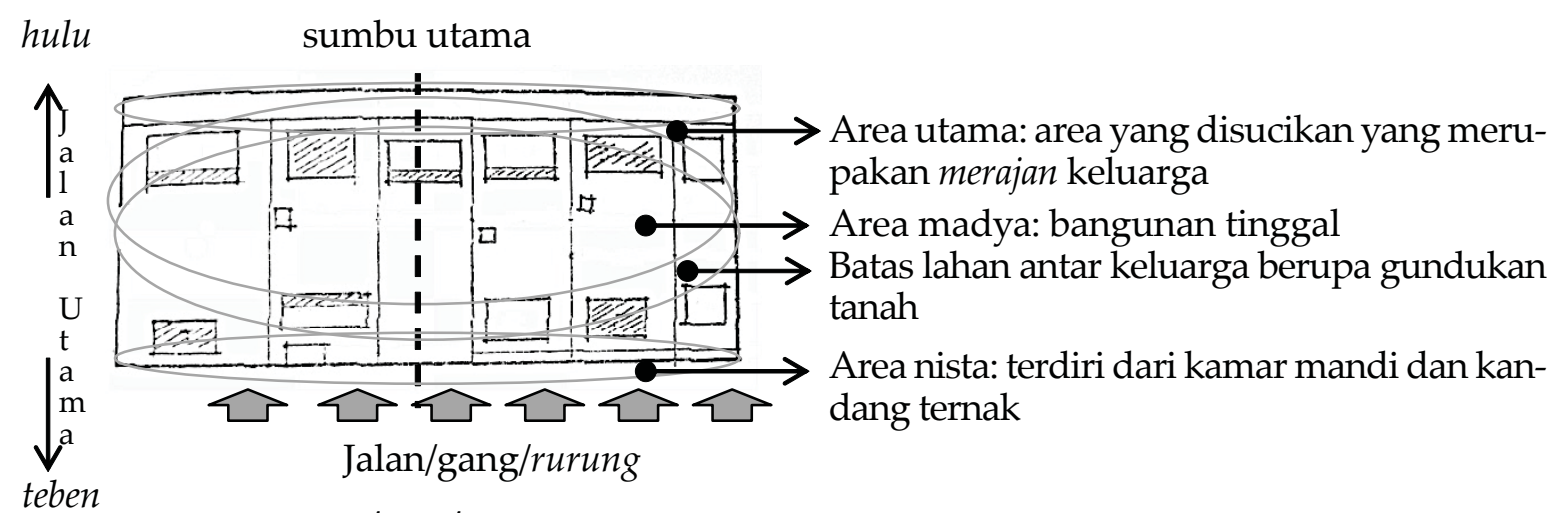

Gambar 3

Pembagian dan tata letak bangunan dalam suatu pekarangan hunian di desa Pinggan, Kintamani, Bangli Sumber gambar: Maharani, 2000

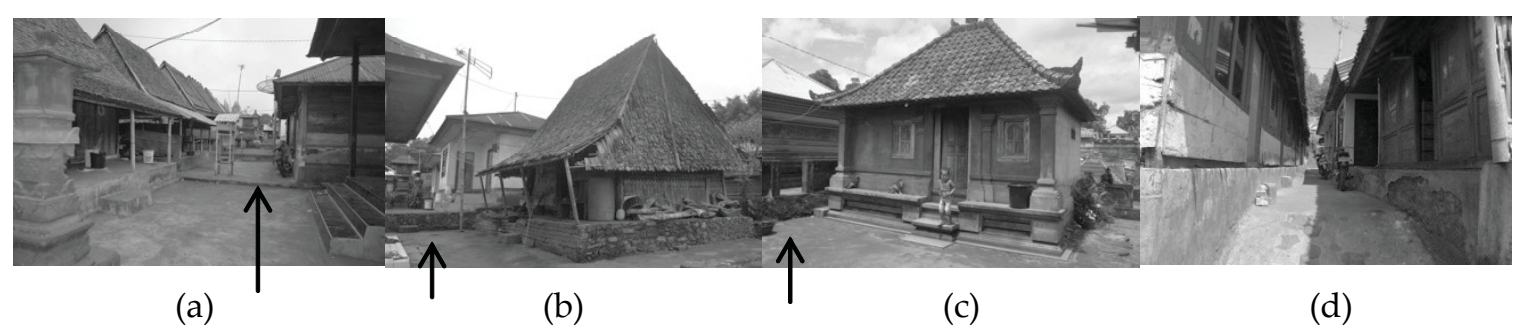

Gambar 4

Tanda batas kepemilikan lahan dengan gundukan tanah (a), perbedaan level lahan (b), tembok popolan pendek (c) dan yang tanpa tanda batas kepemilikan seperti di desa Sukawana Sumber gambar: dokumentasi penulis, 2015

Sukawana, desa Belandingan dan desa Pengotan. Satu pekarangan hunian biasanya didiami oleh beberapa keluarga yang masih memiliki hubungan kekerabatan. Masingmasing lahan antar keluarga seringkali dibatasi dengan sebuah gundukan kecil, perbedaan level tanah ataupun pagar pendek yang terbuat dari material tanah popolan (namun tetap ada bukaaan kecil yang menjadi akses ke pekarangan tetangga). Berbeda dengan desa-desa Bali Aga lainnya, di desa Sukawana justru tidak terlihat adanya tanda atau simbol batas kepemilikan antar pekarangan satu keluarga dengan keluarga lainnya dan masing-masing bangunan antar keluarga tersebut justru saling menyambung.

\# Tipe Kedua: orientasi utama ke arah jalan utama dan area utama yang berupa penempatan merajan selalu berada di dekat pintu masuk pekarangan. Tipe penataan seperti ini hanya terdapat di desa Tenganan Pegringsingan, kabupaten Karangasem. Konon dengan menempatkan area sakral di dekat pintu masuk diharapkan dapat melindungi para penghuninya dari pengaruh jahat yang terbawa masuk melalui pintu pekarangan. Kata Pegringsingan sendiri berasal dari kata Gering yang berarti sakit dan Sing yang berarti tidak. Pada kain Pegringsingan yang terkenal pun pada awalnya dibuat dengan harapan untuk dapat menghindari suatu wabah penyakit (Suryalaga, 2010). Demikian pula dengan penataan pekarangannya, untuk demi dapat menghindari terjangkitnya penyakit pada penghuninya maka masyarakat Tenganan Pegringsingan selalu menempatkan area sakral di dekat pintu masuk pekarangan (Runa, 2004).

Lalu diikuti ke arah dalam pekarangan 


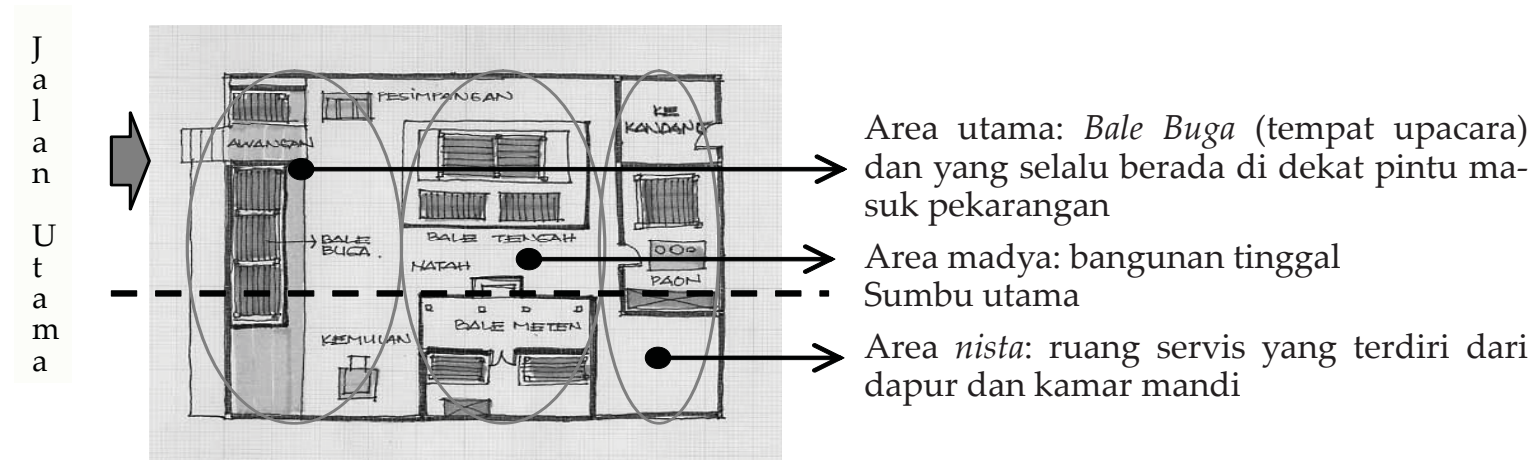

(a)

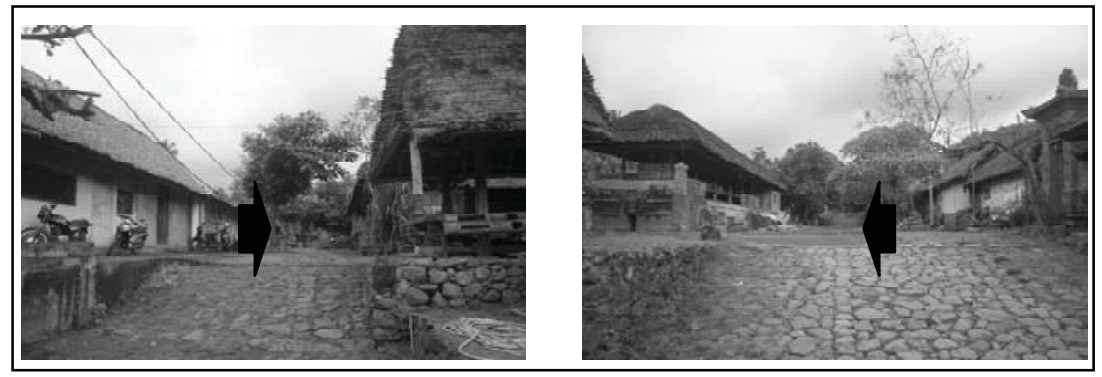

(b)

Gambar 5

Pembagian dan tata letak bangunan dalam suatu pekarangan hunian di desa Tenganan Pegringsingan (a) dan masing-masing hunian yang berada di sisi kiri dan kanan memiliki orientasi yang sama menuju jalan lingkungan desa (b) Sumber gambar: Remawa, 2006 (a), dokumentasi penulis, 2015 (b)

yaitu area madya sebagai area tempat tinggal penghuninya dan area nista yang berada jauh dari pintu masuk pekarangan. Pola ini juga diterapkan pada pekarangan hunian yang berada di seberangnya sehingga secara umum pada permukiman desa ini memiliki pola mirror karena pekarangan hunian di masing-masing sisi jalan akan sama-sama berorientasi ke arah yang sama (ke arah jalan utama lingkungan yang menjadi core desa).

Pada penataan ruang hunian tipe ini dapat dilihat bahwa sumbu utama pada pekarangan hunian tidak lagi mengarah ke gunung sebagai hulu ke arah laut sebagai teben, namun berputar $90^{\circ}$ menjadi dari arah kangin (timur) dan kauh (barat).

\# Tipe Ketiga: orientasi utama adalah arah jalan maupun rurung (gang) di permukiman, namun susunannya kebalikan dari tipe kedua. Pada tipe ini, area utama yang beru- pa merajan berada menjauhi pintu masuk pekarangan, diikuti dengan susunan yang semakin keluar adalah area madya sebagai area tempat tinggal penghuninya dan terakhir berupa area nista yang terdapat kamar mandi dan jineng atau gelebeg di dekat pintu masuk pekarangan. Berbeda dengan desa Tenganan Pegringsingan yang menjadikan jalan utama lingkungan sebagai satu-satunya core arah orientasi bagi hunian di masing-masing sisinya, maka pada tipe ini juga menggunakan jalan lingkungan termasuk jalan-jalan kecilnya (gang atau rurung) sebagai arah orientasi bagi hunian di masing-masing sisi jalannya. Secara umum pada permukiman desa dengan tipe ini juga menimbulkan pola mirror karena pekarangan hunian di masingmasing sisi akan sama-sama berorientasi ke jalan.

Area utama tidak selalu menuju ke arah hulu yang menunjukkan arah gunung, na- 


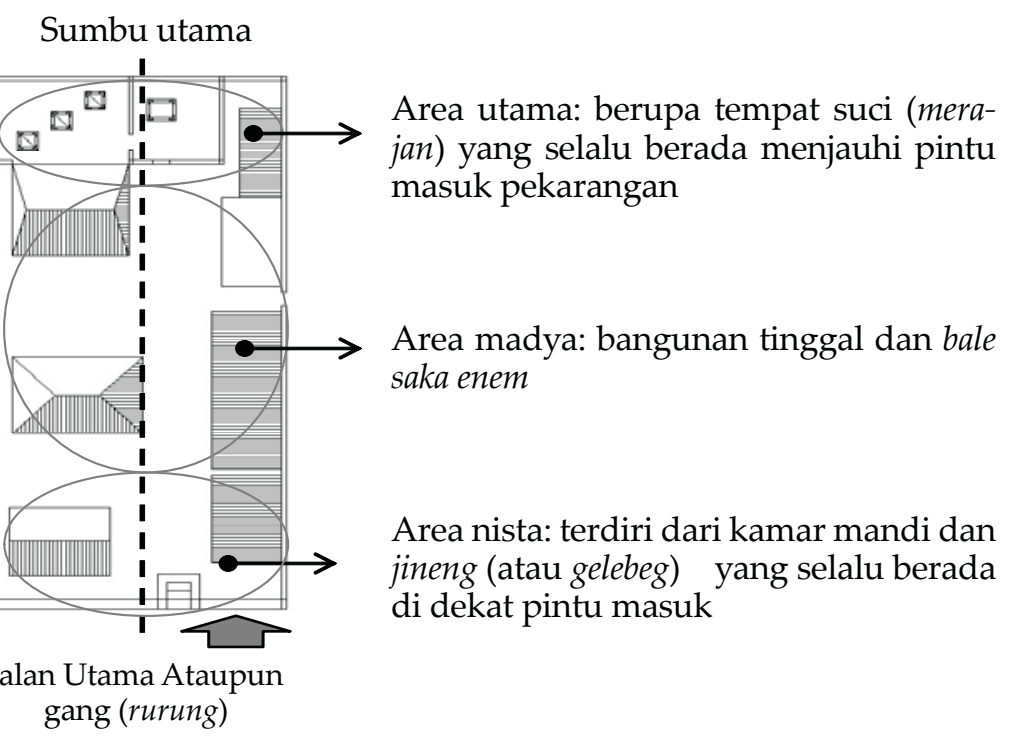

(a)

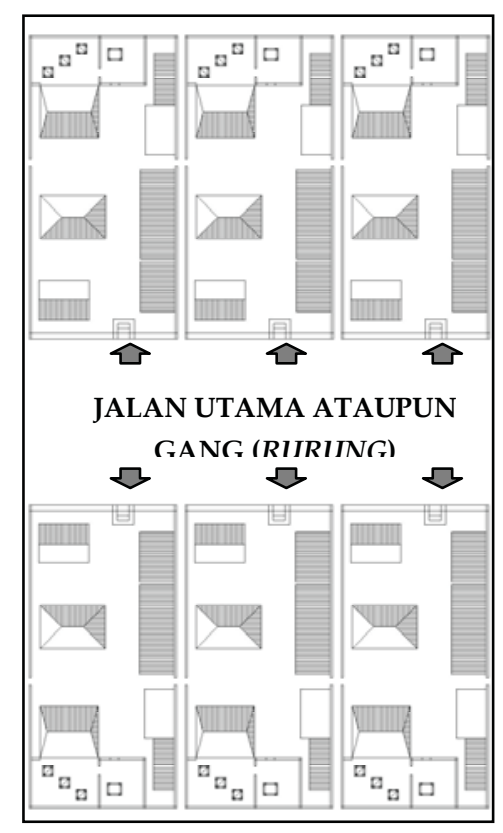

(b)

Gambar 6

Pembagian dan tata letak bangunan dalam suatu pekarangan hunian di desa Bayung Gede (a), konsep mirror untuk penataan pekarangan hunian di masing-masing sisi jalan (b)

Sumber gambar: dokumentasi penulis, 2015

mun pada tipe ini posisi area utama selalu berada menjauhi jalan. Tipe ini hanya terdapat di desa Bayung Gede, Bangli. Pada penataan ruang hunian tipe ketiga ini dapat dilihat bahwa sumbu utama memiliki dua tipe yaitu mengarah hulu ke teben, dan yang berputar $90^{\circ}$ menjadi dari arah kangin (timur) ke kauh (barat).

\section{B. Tata Ruang Dalam Bangunan Hunian}

Berbeda dengan bangunan hunian Bali Madya yang berada di Bali dataran (bukan pegunungan) yang terdiri dari beberapa bangunan yang memiliki masing-masing fungsinya, bangunan hunian Bali Aga pada awalnya merupakan bangunan tunggal dengan fungsi untuk mewadahi berbagai aktifitas dilakukan di dalamnya, seperti kegiatan sehari-hari hingga penyelenggaraan upacara keagamaan seperti upacara pernikahan dan tempat untuk meletakkan jenasah. Pada tata ruang dalam bangunan huniannya, juga dapat dilihat pembagian area utama- madya-nista. Penataan ruang dalam ini juga menjadikan arah ke gunung menjadi orientasi yang utama. Masing-masing bangunan hunian Bali Aga ini terdapat area yang berupa satu ruang khusus yang disucikan. Dari hasil observasi lapangan dapat dilihat ada dua tipe tata ruang dalam bangunan hunian Bali, yang dibedakan atas ada dan tidaknya perbedaan level lantai dalam menunjukkan hirarki nilai-nilai kosmologi.

\# Tipe Pertama: tidak ada perbedaan level lantai antara ruang suci dan tempat tidur (contoh banguan hunian di desa Belandingan, Kintamani, Bangli). Ruang suci dan tempat tidur berada pada satu level yang sama ketinggian $+/-50 \mathrm{~cm}$ dari lantai. Penataan ruang dalam bangunan hanya dibedakan akan posisi berdasarkan perbedaan nilai kesakralannya. Area sakral secara konsisten ditempatkan di arah hulu atau menuju gunung, sedangkan area servis ditempatkan di area teben atau arah menuju laut. 


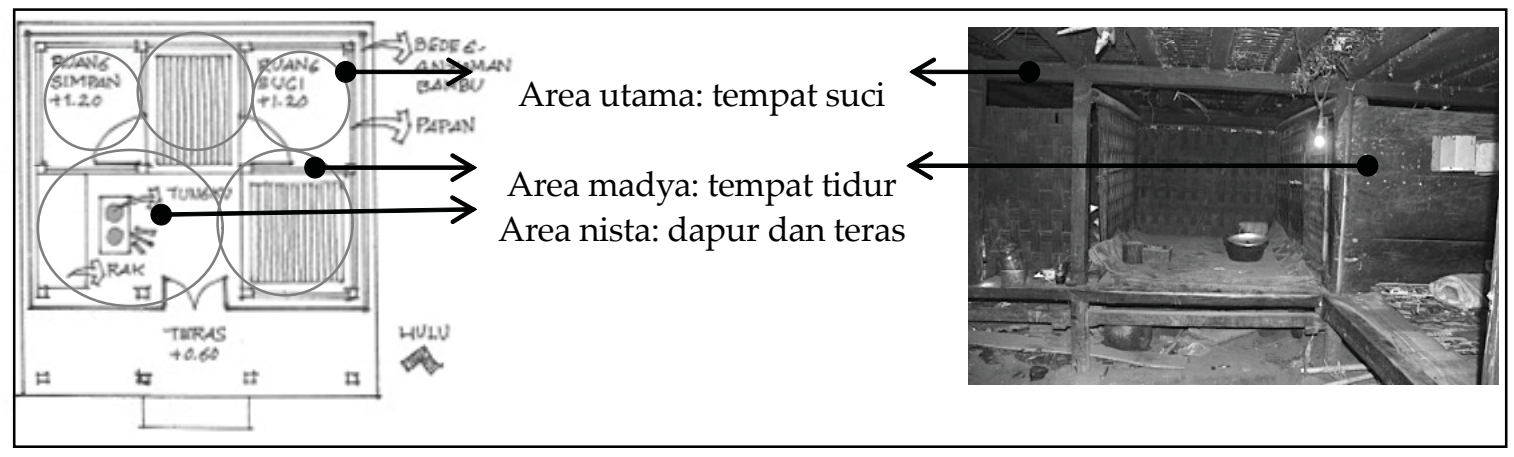

Gambar 7

Tata ruang dalam bangunan hunian di desa Belandingan Sumber gambar: dokumentasi penulis, 2015

\# Tipe Kedua: terdapat adanya perbedaan level lantai untuk menunjukkan hirarki nilai ruang suci, tempat tidur dan ruang yang bernilai nista (contoh banguan hunian di desa Sidatapa, Buleleng). Pada hunian di desa ini pembagian area utama-madya-nista juga direpresentasikan dengan perbedaan level lantai yang masing-masing dibedakan dengan ketinggian $+/-30 \mathrm{~cm}$. Level lantai tertinggi digunakan sebagai tempat pemujaan dan ruang tidur yang bisa sekaligus sebagai tempat upacara seperti upacara pernikahan dan tempat meletakkan jenasah. Level lantai yang lebih rendah merupakan area dapur dengan tungkunya serta tempat bale-bale untuk tempat duduk bersantai. Level terendah adalah teras pada bagian depan bangunan. Semakin bertambahnya anggota keluarga, seringkali bagian teras diambil sebagian ruangannya untuk dijadikan sebagai kamar tidur.

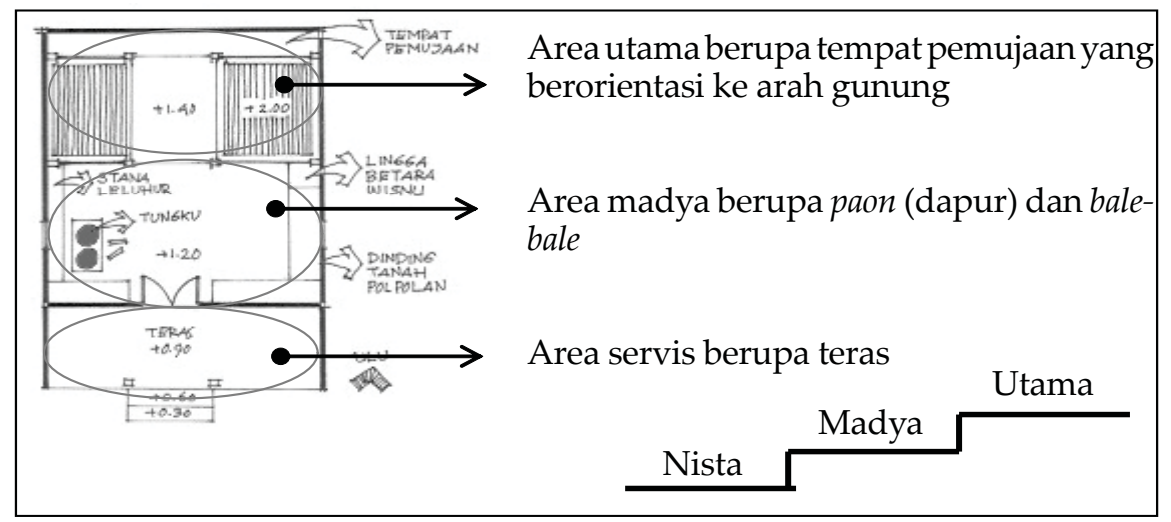

(a)

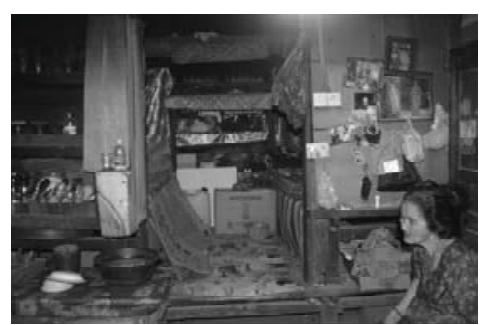

(b)

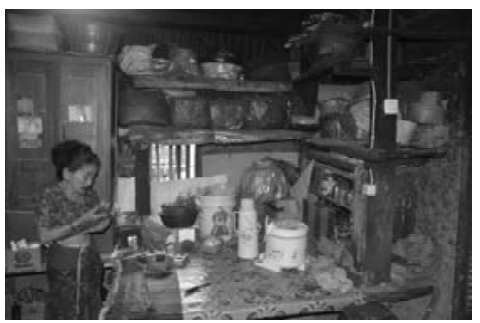

(c)

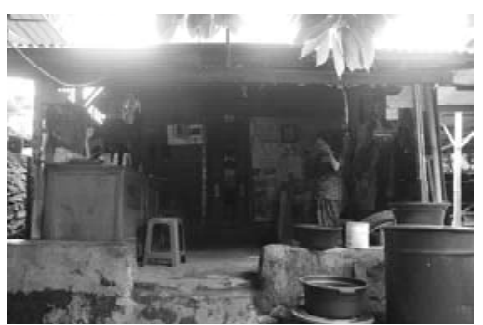

(d)

Gambar 8

Tata ruang dalam bangunan hunian di desa Sidatapa (a), dengan posisi ruang suci pada level lantai yang tertinggi (b), ruang dapur pada level lantai menengah (c) dan teras pada level lantai terendah (d)

Sumber gambar: dokumentasi penulis, 2015 


\section{Tampilan Fisik Bangunan Hunian}

Bangunan hunian Bali Aga memiliki tiga pembagian tampilan fisik seperti halnya bangunan-bangunan hunian lainnya di Bali. Konsep utama-madya-nista direpresentasikan dengan mengambil analogi dari pembagian fisik manusia sebagai pengejawantahan alam spiritual dan alam semesta. Hal yang dianalogkan secara fisik antara manusia dengan perwujudan karya arsitektur tersebut adalah kepala, badan dan kaki. Pada bangunan dipersonifikasikan dengan atap, dinding bangunan dan bebaturan pada bangunan. Perbedaannya adalah bahwa bangunan hunian Bali Madya memiliki proporsi bagian badan bangunan yang lebih tinggi daripada pada bangunan hunian Bali Aga.
Pada bangunan hunian Bali Aga, material bangunan yang dipergunakan masih didominasi dengan penggunaan material yang diperoleh dari lingkungan sekitarnya dan lalu diolah sendiri. Material yang sering digunakan adalah kayu, bambu dan tanah popolan (tanah liat yang dipadatkan). Bangunan hunian Bali Aga memiliki sedikit bukaan, yang dimaksudkan untuk dapat lebih melindungi para penghuninya dari lingkungan sekitar. Bangunan hunian yang menggunakan anyaman bambu sebagai material dindingnya, lubang-lubang kecil pada anyaman tersebut dimanfaatkan untuk lubang sirkulasi udara. Sedangkan bangunan hunian yang menggunakan tanah popolan sebagai material dinding, terdapat lubang atau jendela kecil yang diposisikan di dekat tungku sebagai tempat sirkulasi udara.

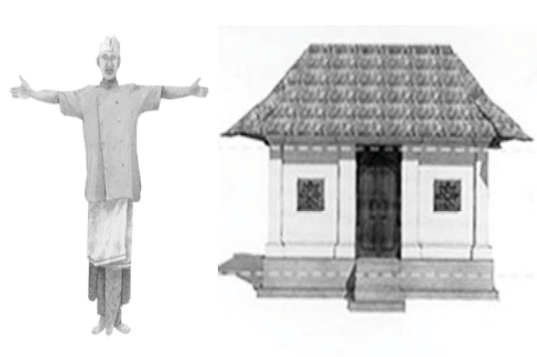

(a)

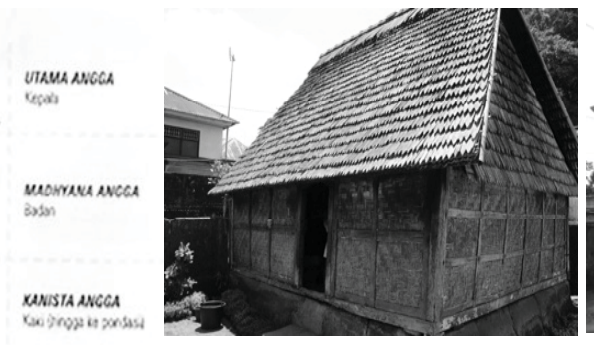

(b)

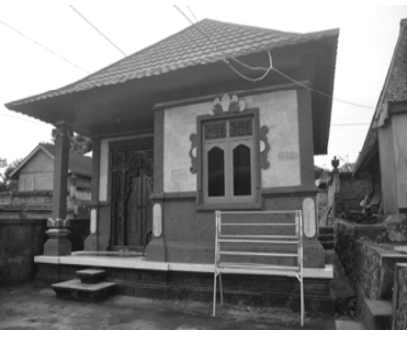

(c)

Gambar 9

Proporsi bangunan hunian Bali Aga yang mengikuti pembagian tiga bagian tubuh manusia (a), contoh bangunan hunian di desa Penglipuran (b) dan perbedaannya dengan proporsi bangunan Bali Madya (c) Sumber gambar: Davison, 2003 (a kiri), Arrafiani, 2012 (a kanan), dokumentasi penulis, $2015(\mathrm{~b}-\mathrm{c})$

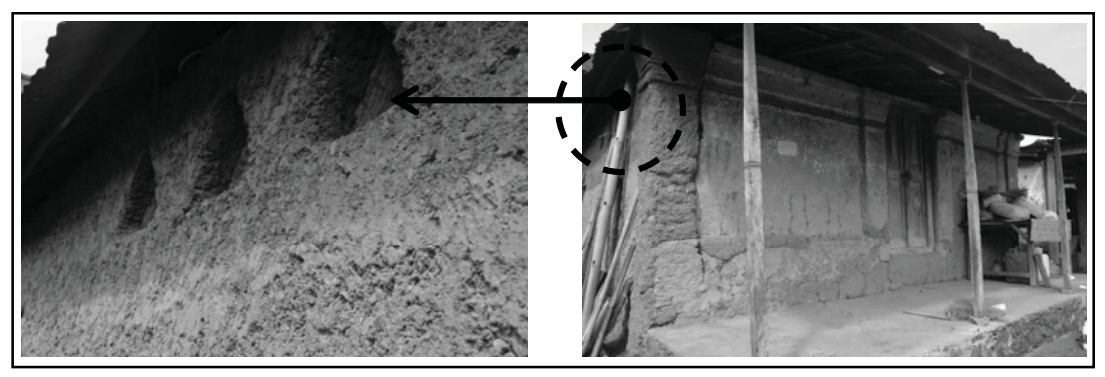

Gambar 10

Bukaan yang minimum pada bangunan hunian di desa Tigawasa Sumber gambar: dokumentasi penulis, 2015. 


\section{SIMPULAN}

Hasil penelitian sebelumnya dan wacana-wacana tertulis tentang Bali Aga cenderung mengeneralisasikan konsep-konsep yang terdapat pada arsitektur Bali Aga. Pada pembahasan dalam penelitian ini terlihat adanya beberapa varian perwujudan arsitekturnya yang ternyata sangat dipengaruhi oleh kepercayaan lokal masing-masing desa Bali Aga, walaupun sebenarnya memiliki nilai dan tujuan yang sama.

Pada tata ruang permukiman dapat dilihat bahwa secara keseluruhan suatu permukiman berorientasi utama ke arah hulu atau gunung. Hal ini ditandai dengan selalu adanya jalan utama yang menjadi core permukiman yang membentang dari arah hulu ke teben (atau ke arah laut). Sisi kanan dan kiri jalan lingkungan utama ini kemudian tersebar jalan lingkungan yang lebih kecil atau gang (rurung). Sering dikatakan bahwa desadesa Bali Aga memiliki pola fish bone atau menyerupai tulang ikan. Kondisi lahan pegunungan yang bertransis hingga kini masih dimanfaatkan dengan baik oleh masyarakat Bali Aga untuk membedakan masing-masing area yang bernilai utama-madya-nista (tidak ada upaya dari mereka untuk melakukan pengurugan lahan). Area utama dianggap bersifat sakral dengan menempatkan pura di ujung hulu permukiman, dan sebaliknya area nista ditandai dengan penempatan kuburan desa di ujung teben permukiman. Pemanfaatan perbedaan transis ini memperlihatkan adanya upaya masyarakat Bali Aga untuk tidak merusak dan justru berupaya menyatu dan menjadi bagian dari alam lingkungannya. Maka dalam sebuah permukiman Bali Aga selalu dapat dilihat bahwa indikatorindikator kosmologikal yang berupa sumbu utama (axis) hulu-teben, perbedaan level lahan dan pola ruang berdasarkan perbedaan nilai-nilainya, memang keberadaannya sangat general dan sama antara satu desa Bali Aga yang satu dengan yang lainnya.

Adanya jalan lingkungan utama sebagai core permukiman yang membentang dari hulu ke teben, menyebabkan penataan pekarangan masing-masing hunian di sebagian besar desa Bali Aga juga mengikuti arah jalan lingkungan utama dengan menjadikan area hulu dari masing-masing pekarangan hunian sebagai area yang sakral. Namun dari hasil observasi lapangan yang penulis lakukan di lapangan terlihat ada beberapa varian yang menjadikannya sebuah keunikan tersendiri. Seperti yang terdapat pada desa Tenganan Pegringsingan yang justru selalu menempatkan area utama (sakral) di dekat pintu masuk pekarangan (berada di hulu sebuah pekarangan, namun selalu berdekatan dengan pintu masuk pekarangan). Demikian halnya dengan penataan pekarangan di desa Bayung Gede yang tidak seperti penataan pekarangan seperti di desa-desa Bali Aga pada umumnya. Kebalikannya dengan penataan pekarangan di desa Tenganan Pegringsingan, masyarakat di desa Bayung Gede justru menempatkan area sakral menjauhi pintu masuk pekarangan. Hal ini dimaksudkan untuk dapat melindungi area paling sakral pada sebuah pekarangan yang selalu dianggap sebagai pelindungnya hunian. Di desa ini selalu diawali dengan area nista ketika memasuki pekarangannya, dengan menempatkan kamar mandi di dekat pintu masuk pekarangan. Hal ini dimaksudkan agar orang-orang yang datang pulang atau berkunjung, selalu membersihkan diri terlebuh dahulu sebelum memasuki area madya (area tempat tinggal penghuninya). Pada kedua contoh tersebut (Tenganan Pegringsingan dan Bayung Gede) dapat terlihat bahwa penataan pekarangan bisa menjadi sangat variatif dan hal ini dipengaruhi oleh kepercayaan lokal mereka terhadap alam lingkungannya. Adanya variasi penataan ruang hunian ini mengakibatkan sumbu utama dalam sebuah pekarangan tidak lagi menuju hulu-teben (kaja-kelod atau gunung-laut), telah berputar kangin-kauh. Namun sebenarnya kedua tipe penataan ini memiliki sumber pendekatan yang sama yaitu 
bagaimana masyarakat dari kedua desa ini merespon apa yang terbawa dari luar pekarangan huniannya.

Sedangkan pada penataan ruang dalam huniannya, mayoritas pada sebagian besar desa Bali Aga masih menempatkan area sakral pada arah hulu. Namun yang menjadi variasi di sini adalah pertama, tidak adanya perbedaan level lantai hunian yang dapat membedakan area berdasarkan hirarki nilai sakral-madya-nista dan kedua, adanya perbedaan level yang secara tidak langsung memudahkan dalam mengenali masing-masing area berdasarkan nilainya. Perbedaan level lantai hunian seperti yang terdapat pada hunian di desa Sidatapa ini konon juga untuk dapat melindungi penghuninya dari lingkungan sekitarnya. Semakin tinggi level lantai maka dianggap semakin bisa melindunginya dari ancaman lingkungan sekitar.

Hunian-hunian ini memiliki beberapa kesamaan secara fisik luar bangunannya. Pertama, bangunan memiliki proporsi yang sama dengan bagian tubuh manusia yang dibagi menjadi bagian kepala (atap bangunan), badan (dinding bangunan) dan kaki (bebaturan). Berbeda dengan hunian-hunian dari periode selanjutnya (Bali Madya), hunian Bali Aga memiliki bagian dinding bangunan yang cenderung rendah dengan jarak lantai ke plafon $+/-220 \mathrm{~cm}$. Kedua, hunian-hunian Bali Aga memiliki kesamaan menggunakan material-material bangunan yang berasal dari lingkungan sekitarnya seperti kayu, bambu dan tanah popolan (tanah liat yang dipadatkan). Hal ini dikarenakan belum adanya material-material pabrikasi pada jaman tersebut (Bali Aga berasal dari periode abad ke-8 s/d 13) sehingga mengharuskannya mengambil material dari alam. Namun justru dengan menggunakan material-material alam tersebut membuat hunian terlihat dapat lebih menyatu dengan alam sekitarnya.

Pada pembahasan di atas, dapat dilihat bahwa masyarakat Bali Aga masih sangat tergantung dan selalu berusaha menyatu de- ngan alam lingkungannya tanpa merusaknya. Kepercayaan bahwa mereka merupakan bagian dari alam (makrokosmos), maka masyarakat Bali Aga menyebutnya sebagai konsep Manik Ring Cucupu, yang mengandaikan ibarat janin dalam rahim. Akan terjadi hubungan timbal balik, jika rahim rusak maka janin pun menjadi sekarat. Masyarakat Bali Aga percaya apabila mereka merusak alam maka merekalah juga yang akan terkena imbasnya. Cara mereka beradaptasi dengan lingkungannya sangat variatif, namun tetap sama pada satu tujuan dengan memandang alam sebagai arah orientasi dengan masingmasing nilai utama, madya dan nista.

\section{Daftar Pustaka}

A.A. Gde Rai Remawa, dkk

2006 Studi Desain Interior Rumah Tinggal Tradisional Bali Age (Bali Pegunungan). Denpasar: Institut Seni Indonesia Denpasar

Arrafiani

2012 Rumah Etnik Bali. Depok: Griya Kreasi

Davison, Julian

2003 Introduction to Balinese Architecture. Singapore: Periplus

Ida Ayu Dyah Maharani

2000 Pengembangan dan Penataan Permukiman di Desa Pinggan. Bali: Program Studi Arsitektur, Universitas Udayana

I Wayan Ardika, dkk

2013 Sejarah Bali dari Prasejarah Hingga Modern. Denpasar: Udayana University Press

I Wayan Runa

2004 Sistem Spasial Desa Pegunungan di Bali dalam Perspektif Sosial Budaya. Yogyakarta: Program Doktor, Universitas Gadjah Mada 
I Wayan Runa

2007 Rumah Tinggal Desa Tenganan Pegringsingan. Bali: Fakultas Teknik, Universitas Warmadewa

I Wayan Yuda Manik

2007 Pengaruh Demografi, Gaya Hidup dan Aktifitas Terhadap Transformasi TipoMorfologi Hunian Tradisional di Desa Bayung Gede, Bali. Bandung: Program Pascasarjana Arsitektur, Institut Teknologi Bandung

\section{Marcus Gartiwa}

2011 Morfologi Bangunan dalam Konteks Kebudayaan. Bandung: Penerbit Muara Indah
Putu Suryalaga

2010 Penataan Desa Adat Tenganan Pegringsingan, Karangasem. Bali: Program Studi Arsitektur, Universitas Udayana

Reuter, Thomas A.

2005 Custodians of The Sacred Mountains (Budaya dan Masyarakat di Pegunungan Bali). Jakarta: Yayasan Obor Indonesia

Wahid dkk

2013 Teori Arsitektur Suatu Kajian Perbedaan Pemahaman Teori Barat dan Timur. Yogyakarta: Graha Ilmu 